Rapp. Grønlands geol. Unders. 79, 35-44 (1977)

\title{
FIELDWORK ON UBEKENDT EJLAND IN THE TERTIARY BASALT PROVINCE OF WEST GREENLAND 1971 AND 1973
}

\author{
Jørgen Gutzon Larsen
}

A summary of the geology of Ubekendt Ejland has been given by Drever \& Game (1948) and Drever (1958). The present author started fieldwork as a member of Professor Drever's expedition in 1971 and continued work in 1973 as a member of GGU's mapping team.

\section{Structure}

As shown by Drever \& Game (1948), Drever (1958 and unpublished map) and Henderson (unpublished photogeological interpretation) the lavas dip towards the south-western corner of the island from the two topographically high areas in the north and south of the island to form a broad syncline with WSW-pitching axis (fig. 17). The dip of the lavas is nearly at right angle to the existing faults, and thus indicates that the syncline could have been caused by tilting as a consequence of faulting. On the south-west coast of the island, the dips change from NW west of Qeqertalik to SW in the area near Tuperssuartâ; in this case the change seems to be caused by two discordances within the sequence.

\section{Stratigraphy}

The total thickness of the volcanics on Ubekendt Ejland is not accurately determined owing to repetitive faulting with resulting numerous repetitions of the sequence. Drever \& Game (1948) and Drever $(1958,1967)$ have estimated the thickness of the volcanic pile to be more than $10 \mathrm{~km}$, not having considered the faulting. The present author arrived at atal of $14 \mathrm{~km}$ calculated along a line from Íngia to Tuperssuartâ; this thickness is reduced to 10 $\mathrm{km}$ by the known displacements. The monotonous sequences of picrite flows may, however, conceal additional repetitions.

Drever \& Game (1948) divided the volcanics into a Lower Lava Group of picrite basalts and an Upper Lava Group of more varied rock types. This division would roughly correspond to the Vaigat Formation and the Maligât Formation in other parts of the Tertiary Basalt Province of West Greenland (Pedersen, 1969, 1973; Hald, 1973; Hald \& Pedersen, 1975). On Ubekendt Ejland and on southern parts of Svartenhuk Halvø (Pulvertaft \& Clarke, 1966) a transitional development from nearly pure picritic lavas to the non-picritic of the Upper Lava Group has been observed. For this reason it seemed desirable to divide the volcanics into: 




Fig. 17. Sketch map of Ubekendt Ejland. Dykes and Quaternary deposits are not shown.

(1) a lower formation.

(2) a transitional formation.

(3) an upper formation.

But the informal division previously established in other areas of West Greenland will be retained in this note. 


\section{The lower lava formation}

The lavas exposed on the north-west coast from Íngia to Qârusuk, where the sequence of basalt is approximately $100 \mathrm{~m}$ thick, are used to define the lower formation. The exposed thickness of a maximum of $5 \mathrm{~km}$ consists of picrite basalts with few olivine basalt flows (fig. 18). On the south coast the upper boundary of the formation is tentatively placed at the prominent basalt escarpment of Naqerdlup qáqâ.

The lavas can be divided into two types, pahoehoe lavas and lavas with scoriaceous top zones. The first type comprise the typical picrite basalt, and the second type has a range from nearly aphyric basalts to picrite basalts. This distinction is similar to the one made by Pedersen (1970) on Disko.

Individual pahoehoe picrite flows are usually $0.5-3 \mathrm{~m}$ thick, but there is a complete transition to thin units made up of $10-30 \mathrm{~cm}$ thick pahoehoe toes (fig. 19). Flows up to $25 \mathrm{~m}$ thick have been recorded (Drever, 1958). Frequently the thin flows are very impersistent and lens-shaped, separated by thin chilled tops of red colour. Such flow-units can build up uniform sequences from 10 to $60 \mathrm{~m}$ thick (fig. 20). These are occasionally overlain by red sedimentary horizons less than $0.5 \mathrm{~m}$ thick.

As pointed out by Drever \& Game (1948), the picritic flows are characterized by vesicular (actual amygdaloidal) banded top zones (fig. 21), which can amount to more than 50 per cent of the thin flows and less in the thicker flows. The description of the typical picrite basalt flows from Svartenhuk Halvø and Baffin Island (Clarke \& Upton, 1971) also fits the lavas on Ubekendt Ejland.

In the field it is possible to distinguish between three rock types of the pahoehoe picrite basalts:



Fig. 18. Picrite basalt flows from the east coast of Ubekendt Ejland showing massive lenses and zeolite-filled vesicular bands. Cliff is about $200-250 \mathrm{~m}$ high. 


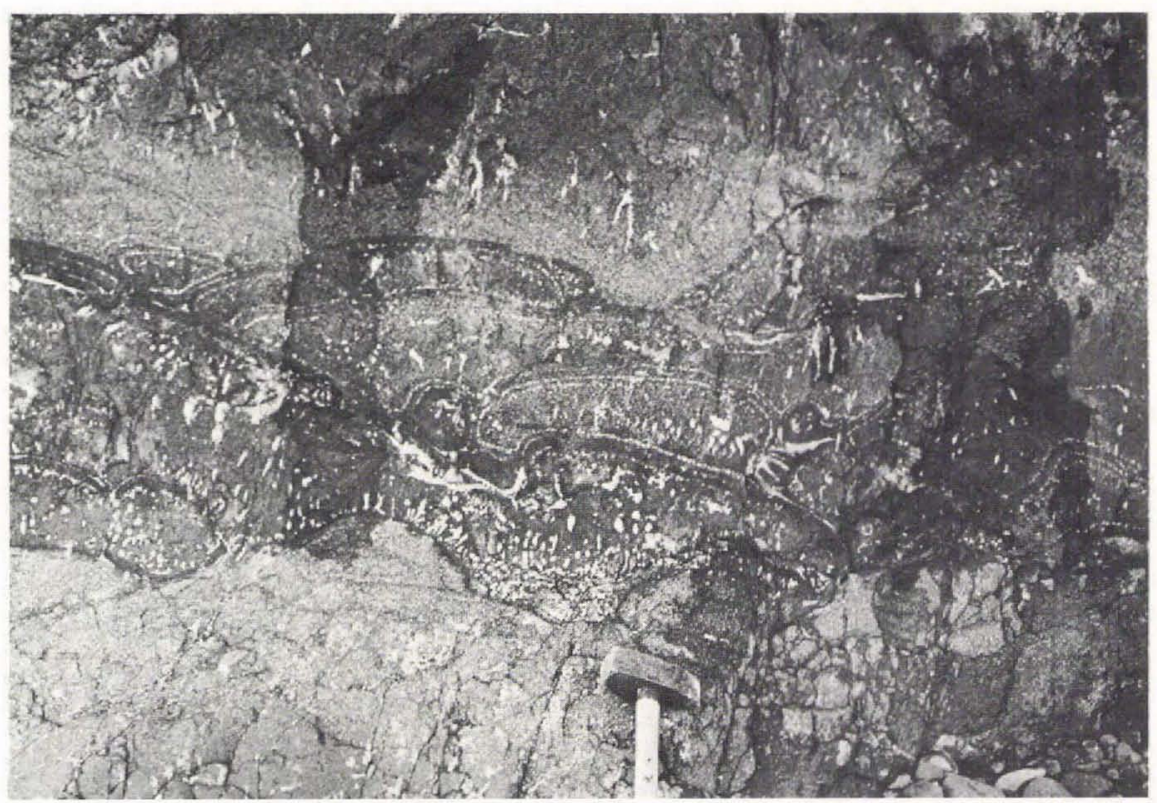

Fig. 19. Pahoehoe toes in picrite basalt.

(1) An aphyric fine-grained to medium-grained type, usually with only few olivine phenocrysts bigger than $1 \mathrm{~mm}$ in diameter. This type is very common and probably corresponds to the pahoehoe picrite basalts on Disko described by Pedersen (1970).

(2) Thick flows or lenses may be closely packed with equidimensional olivine phenocrysts, $1-5 \mathrm{~mm}$ across in a fine-grained groundmass. There are transitions between type one and type two. Gravitative cumulation of olivine in these flows has not been observed, but may have occurred between the amygdaloidal banded top and the massive part of the flow.

(3) A few rotten picrite basalts are packed with up to $1 \mathrm{~cm}$ long platy olivine phenocrysts.

The scoriaceous olivine basalts are typically $3-10 \mathrm{~m}$ thick with $0.5-3 \mathrm{~m}$ thick scoriaceous top zones and usually thin amygsaloidal bases. The size of the olivine phenocrysts ranges from less than $1 \mathrm{~mm}$ to $1 \mathrm{~cm}$ across and the shapes are equidimensional. In some flows, richer in olivine, small platy (skeletal) phenocrysts are found. Occasionally these flows contain picritic and ultramafic(?) nodules up to a few centimetres across. The groundmass is fine-grained to dense; these flows are more resistant to erosion than the usual picrite flows. The olivine basalts occur as units composed of several flows. One unit outcrops on the east coast and can be followed for $3.5 \mathrm{~km}$ from Nunánguaq to Ivnârssuit nûkavsait, diminishing in thickness to the north-north-west.

A few aphyric basalts occur in the lower lava formation and are found near Ilimanaq on the coast, in a section in the south-eastern fault block and at Terqiaq. These flows commonly show platy jointing and scoriaceous top zones with thicknesses ranging up to slightly more than $10 \mathrm{~m}$. At Ilimanaq the aphyric basalt is overlain by olivine porphyritic basalts indicating an increase in the olivine content upwards in the sequence. A similar situation is found in one of the olivine basalt sequences in a section near Igdlorssuit. 


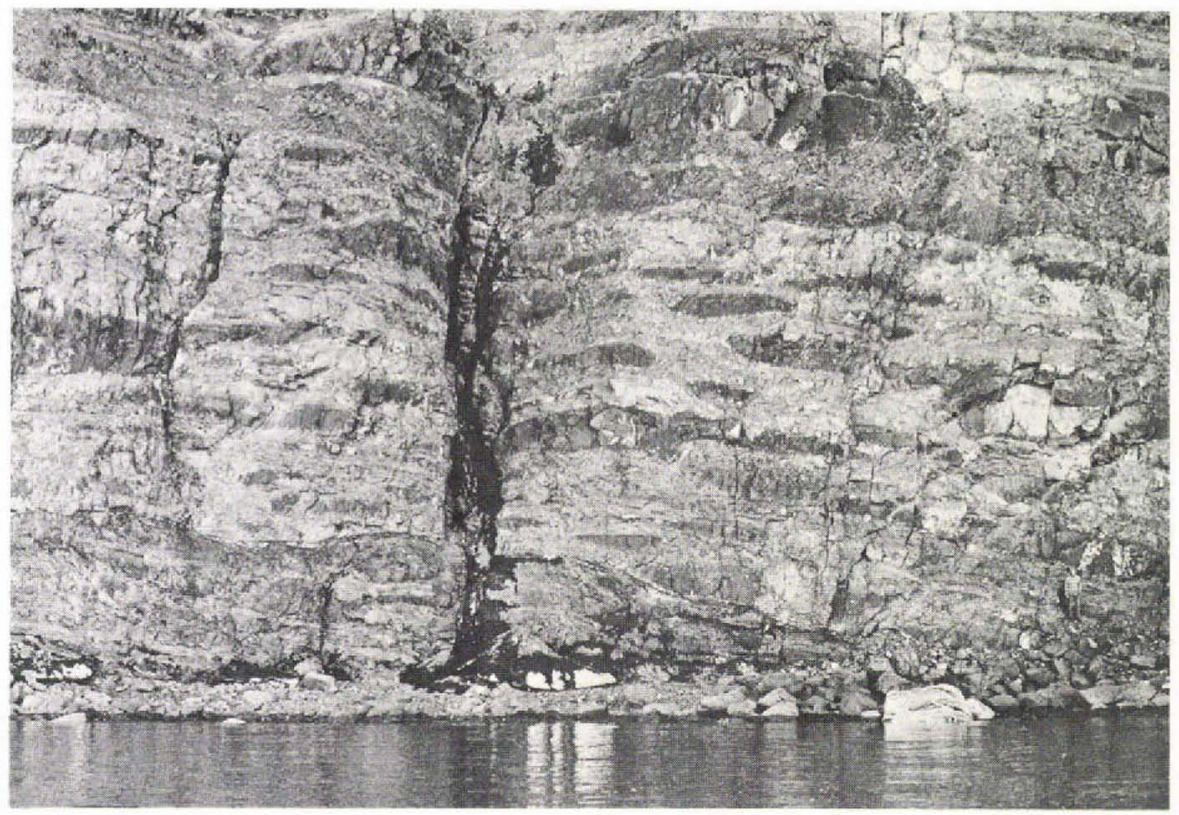

Fig. 20. Picrite basalt sequence comprising numerous flow-units. The person to the right indicates scale.

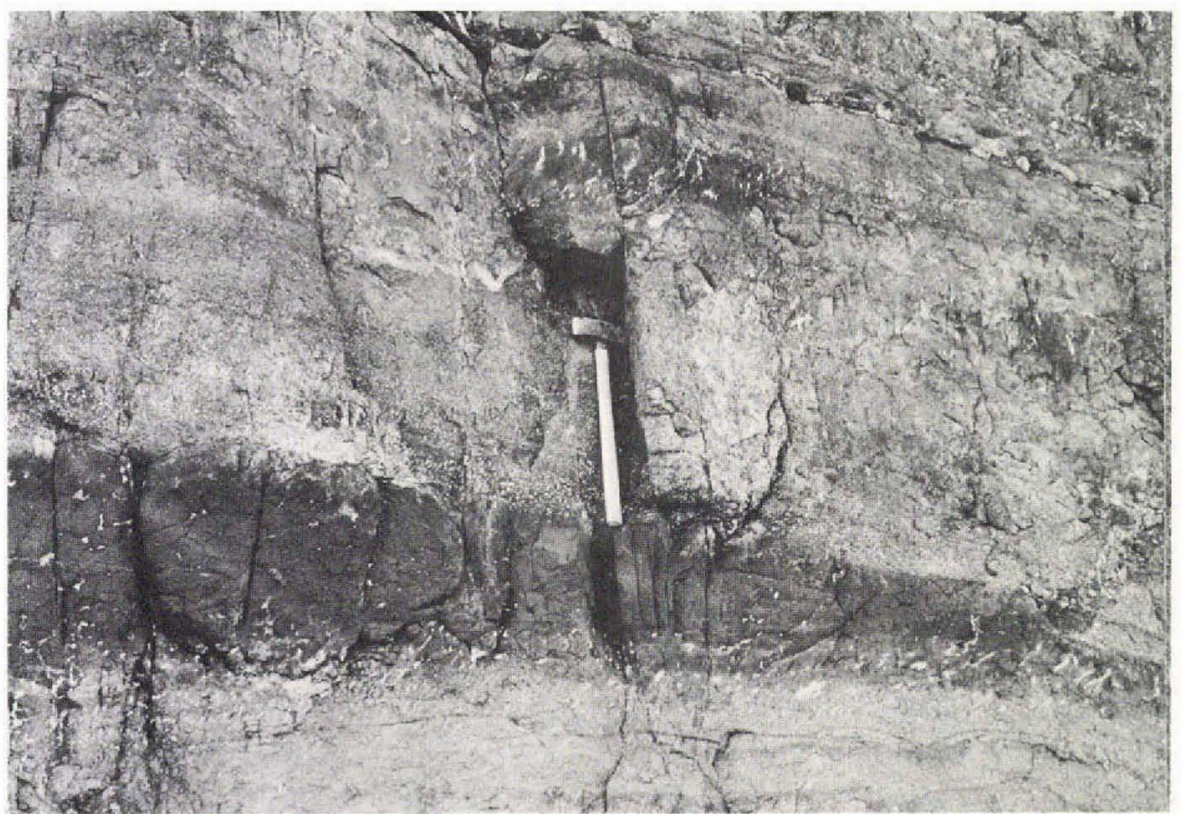

Fig. 21. A single flow unit from a picrite basalt sequence. The base (marked by a smooth dark line) is amygdaloidal and contains irregular pipe amygdules. This zone grades up into a massive layer and then into an amygdaloidal banded top zone. 
Sedimentary or pyroclastic deposits are extremely rare in the lower lava formation and they probably cannot be used for stratigraphic correlation. However, at Ilimanaq there is a $15 \mathrm{~m}$ thick dark greenish-grey clastic unit, which has been useful as a marker horizon to detect the faulting in this part of the coast. The unit is built up of alternating shaly and coarse clastic layers, which near the base carry rounded pebbles up to $10 \mathrm{~cm}$ in diameter. In the section in the south-eastern fault block a similar layer, $5 \mathrm{~m}$ thick, occurs. It is not yet certain whether these units are of purely volcanic origin. At Nũngutak a $4 \mathrm{~m}$ thick tuff carries scattered centimetre-sized xenoliths of granite, quartzite and ultramafic(?) rocks. Further to the east a more than $100 \mathrm{~m}$ thick basaltic agglomerate is overlain by at least one or two basalt flows. Its stratigraphical position is unknown as it is cut off by faults.

\section{The upper lava formation}

\section{The transitional member}

The base of this member is defined above, and the top is placed at the base of a thick pyroclastic deposit occurring on the south-western part of the island. The maximum thickness on the north-west coast is $3 \mathrm{~km}$ and along a line in the dip direction from Naqerdlup qáqâ it is $\mathbf{4} \mathbf{~ k m}$. Volcanic activity continued uninterrupted in the time interval comprising this member and the underlying formation. There can occur intercalations of doleritic plagioclase glomerophyric pahoehoe flows in the dominating picritic flows. These can only be distinguished from the picrite basalts in hand specimen. The picritic flows decrease in number upwards and are replaced by tholeiitic plagioclase glomerophyric and aphyric basalts. On the north-west coast and on the coast around Sarqâta qáqâ hornfelsing of the lavas by the intrusions tends to obscure differences in rock types.

Single basalt flows may reach $30 \mathrm{~m}$ in thickness but commonly are 3-10 m thick with 0.5-3 m thick scoriaceous tops. Scoriaceous bases are rarely found. Aphyric basalts seem to dominate over plagioclase porphyritic basalts on the north-west coast and the opposite seems to be the case on the south-west coast. The lack of marker horizons and poor exposures in the interior of the island make correlation between the two areas impossible with the exception of a $100 \mathrm{~m}$ thick lapilli tuff unit, which is common to both areas. Clarke (1973) has divided the north-west coast into areas dominated either by aphyric and plagioclase porphyritic lavas or by picritic lavas. The present author's investigations show, however, that there is a transition between the two divisions. Clarke (1973) has reported rhyolite flows from Itivnera, but these are here regarded as rhyolitic sills.

\section{The upper member}

The base of this member is formed by a lower pyroclastic unit, $600 \mathrm{~m}$ thick, in Tuperssuartâta kûa. The unit is composed of interbedded altered lapilli tuff and fine tuff, with occasional layers containing big blocks. Basaltic and more differentiated rock types predominate, although a few gabroic xenoliths are present. Components of sedimentary origin have not been identified. In Tuperssuartâta kûa the regional dip is $30-40^{\circ}$ to the south-west, but on the south-west coast the dip increases from $20^{\circ}$ near the base to $60^{\circ}$ at the top. Here the pyroclastics are probably discordantly overlain by a plagioclase porphyritic unit. A 


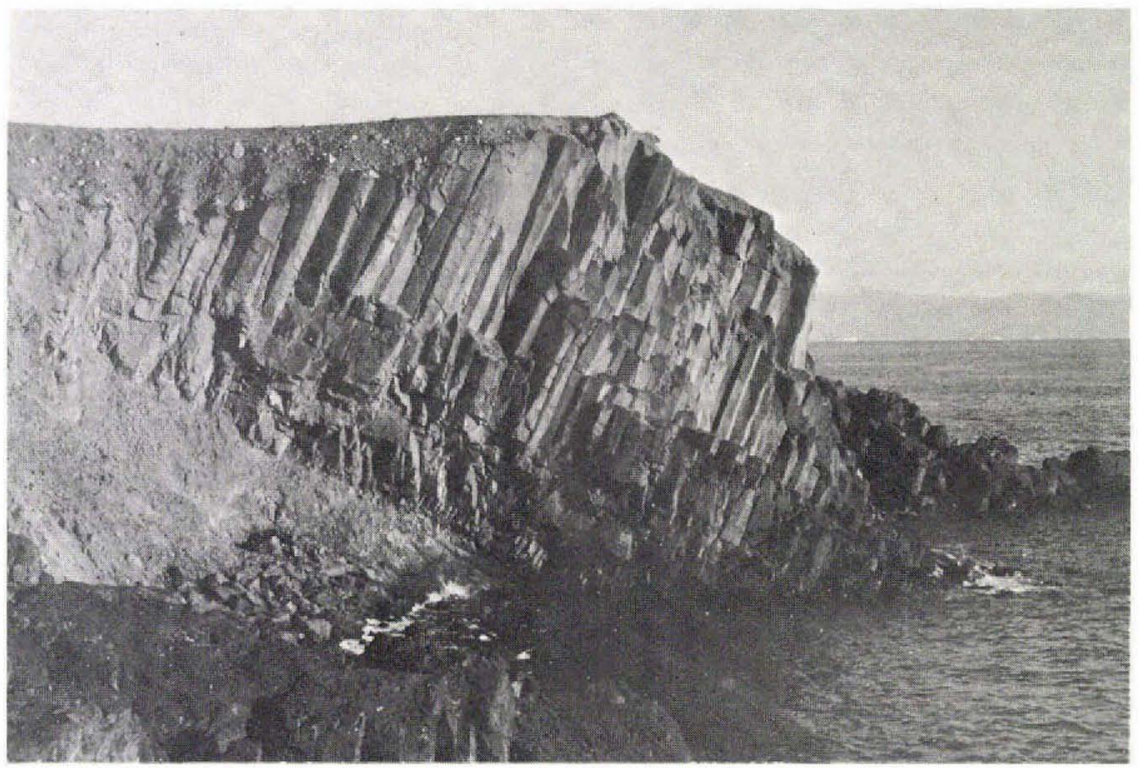

Fig. 22. Columnar jointing in the uppermost basalts near Tuperssuartâ. The columns are approximately $0.5-0.7 \mathrm{~m}$ thick.

similar tuff unit outcrops on the north-west coast. There the distinction between tuff, intrusive breccias and vent agglomerates is very difficult because of the intense carbonatization, and a combination of either inaccessible cliffs or bad exposures. This explains the differences between the map given by Clarke (1973) and the present map where vent agglomerates were differentiated from tuffs by the absence of bedding and the unsorted nature of the pyroclastics.

The pyroclastic unit is overlain by a $200 \mathrm{~m}$ thick plagioclase porphyritic unit with only a few aphyric basalt flows intercalated. The base of this is formed by a $20 \mathrm{~m}$ thick flow on the south-west coast, but normally the thickness of the flows is less than $10 \mathrm{~m}$. Altered tuff layers are present between the flows. Some of the lavas in the upper part of the unit are pahoehoe types, and some have star-aggregated, platy plagioclase phenocrysts exceeding 1 $\mathrm{cm}$ in length. Such rocks are relatively rare in the Tertiary Basalt Province of West Greenland.

The overlying unit comprises $250-300 \mathrm{~m}$ of rhyolitic ignimbrites on the south-west coast, but this unit seems to thin out towards Tuperssuartâta kûa. Clarke (1973) included the unit in the lower pyroclastic unit and suggested a thinning out of the plagioclase porphyritic unit below. This proposal could not be substantiated, as the basalts of this unit overlie the lower pyroclastc unit in Tuperssuartâta kûa.

The ignimbrites are devitrified, white or reddish, and are strongly altered at several localities along the coast. Inland only $1-2 \mathrm{~cm}$ thin slabs can be obtained as samples. Three or four glassy layers occur and are interpreted as bases of cooling units. A pitchstone flow from the base of the ignimbrite unit has been briefly described by Drever \& Game (1948) and Clarke (1973). 
The overlying unit is $200 \mathrm{~m}$ thick and is dominated by laminated aphyric and plagioclase-porphyritic differentiated lavas. Individual flows are from 2 to $5 \mathrm{~m}$ thick and commonly show scoriaceous top zones, which may be strongly altered.

The uppermost basalts are characterized by black columnar jointed basalts (fig. 22) and are estimated to be more than $150 \mathrm{~m}$ thick. The flows are usually more than $10 \mathrm{~m}$ thick and their fragmental top zones can reach up to $4 \mathrm{~m}$ in thickness. Thin tuff layers are present. Olivine, augite and plagioclase are common phenocrysts; the alkaline affinities of at least some of these flows are shown by groundmass olivine and feldspathoids. Nodules of gabbroic and ultramafic rocks in the centimetre size range characterize one of the flows; fragments of bituminous shale have been found in a tuff layer and in a different flow.

\section{Volcanic vents}

The more than $100 \mathrm{~m}$ thick basaltic agglomerate east of Nũngutak (see above) is composed of partly devitrified glassy breccias, bombs and thin lava sheets (fig. 23) and was first mapped by Drever \& Game (1948). Another basaltic agglomerate is found at Qârusuk, it contains big basaltic blocks and a few blocks of granites and gneisses. The volcanic vent near Ivnâ has briefly been described by Drever \& Game (1948) \& Clarke (1973). Blocks in metre size are found here, and there is a range in rock types from basaltic to more rhyolitic composition.

The occurrence of all these pyroclastic rocks strongly suggests the existence of volcanic centres to the south-east, west and north-west.

Whether the Sarqâta qáqâ intrusive complex has acted as a central volcano is not known.

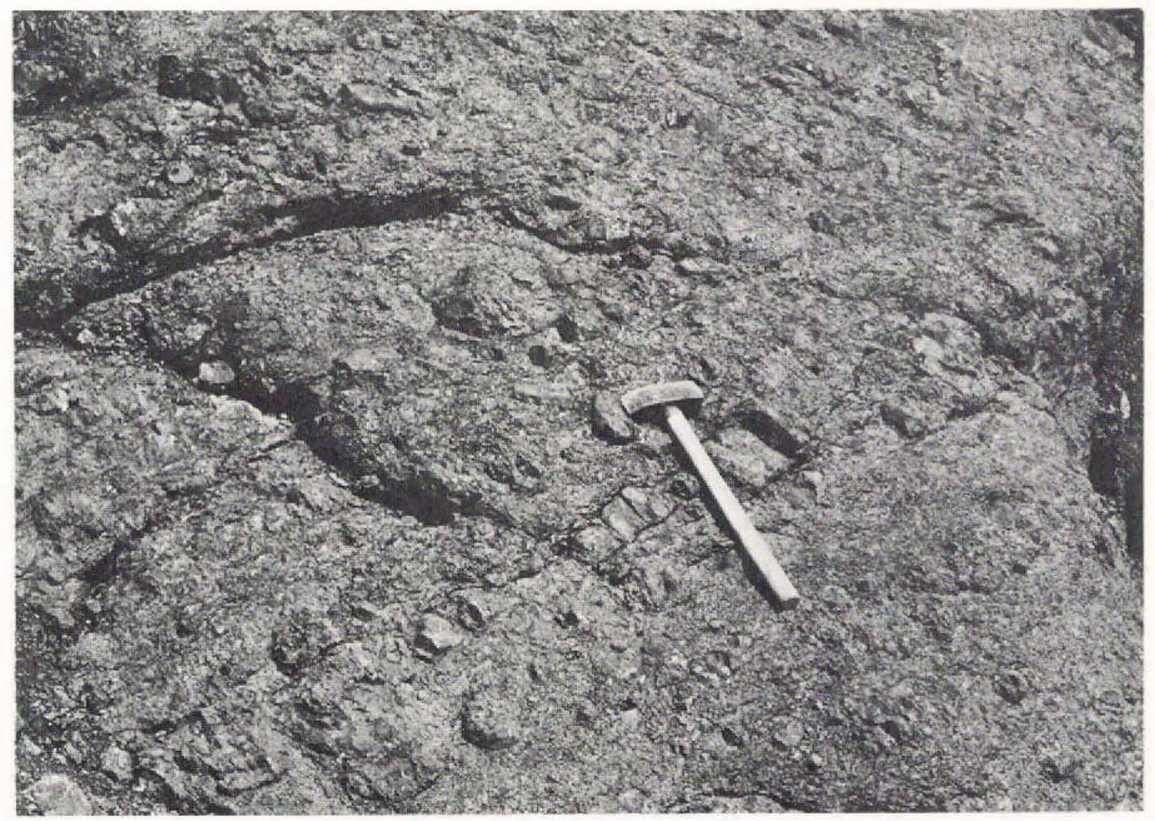

Fig. 23. Agglomerate from south-eastern Ubekendt Ejland. 


\section{Minor intrusions}

The minor intrusions were subdivided by Drever \& Game (1948) into: picrites, tholeiites, composite acid-basic intrusives, acid intrusives, lamprophyres, nepheline basalts, and melilite-nephelinites (Drever \& Gribbon, 1968).

Dykes in the northern and eastern part of the island strike predominantly NE-SW; nearly coast parallel dykes with northerly to north-easterly trends also occur on the east coast. In the northern part of the island the NE-trending dykes are steeply inclined to the north-west, but to the south they are often inclined in the opposite direction. The NEtrending dykes are mainly occupied by aphyric or plagioclase glomerophyric basalt and dolerite. Some greenish sulphide-bearing dykes have the same trend. The same rock types are found in ENE to ESE trending swarms together with most of the picrite and olivine basalt dykes. All these dykes are commonly dipping to the north.

The N to NNW trending lamprophyre dykes on the west coast were briefly described by Drever \& Game (1948) and Clarke (1973). Xenoliths consisting of gneisses, granites, ultramafic and quartzitic rocks occur in these dykes and graphite has been found in one dyke by the present author.

\section{Faulting}

Faulting may well have occurred simultaneously with extrusion of the lavas and intrusion of the dykes, but the magnitude of the movement on these faults cannot be determined. There is clear evidence of considerable late faulting: in the northern part of the island both picritic and basaltic dykes are strongly fractured along fault zones, and on the west coast the margins of lamprophyre dykes are occasionally crushed and carbonatized. The carbonate zones acted as zones of movement and slickensides show dip slip and oblique slip displacement. A small satellite intrusion to the Sarqâta qáqâ intrusive complex is cut by a fault; layering in the intrusion shows much lower dip than the surrounding lavas, which strongly indicates tectonic movements before emplacement of the intrusion.

On the northern part of the island the faults trend in an ESE to SE direction, corresponding to the fault trends observed on Svartenhuk Halvø (Pulvertaft, unpublished map; Münther, 1973). The faults are steeply inclined to the north-east and as proposed by G. Henderson (personal communication) are in antithetic relation to the inclination of the lavas and the inner margin of the West Greenland Cretaceous-Tertiary basin. The vertical displacement along individual faults is in the range of $50-150 \mathrm{~m}$, and the tilting has caused an overall increase in the dip of the lavas from Íngia $\left(16^{\circ}\right)$ to Igdlungnap qáqâ $\left(30^{\circ}\right)$. The large landslide of Igdlorssuit probably has its continuation in one of the SE-trending faults.

Faulting in the south-eastern part of the island has caused displacements of unknown magnitude along NNE-SSW trending faults, which may correspond to the directions of some of the faults found on Nûgssuaq by Münther (1973) and Hald (1973).

\section{References}

Clarke, D. B. 1973: New mapping in the western part of Ubekendt Ejland. Rapp. Grønlands geol. Unders. 53, 5-9. 
Clarke, D. B. \& Upton, B. G. J. 1971: Tertiary basalts of Baffin Island: field relations and tectonic setting. Can. J. Earth Sci. 8, 248-258.

Drever, H. I. 1958: Geological results of four expeditions to Ubekendt Ejland, West Greenland. Arctic, 11, 198-210.

Drever, H. I. 1967: The lower lava group and associated picritic minor intrusions on Ubekendt Ejland, West Greenland. Proc. geol. Soc. Lond. 1967 [No 1637], 52-53.

Drever, H. I. \& Game, P. M. 1948: The geology of Ubekendt Ejland, West Greenland, part I, a preliminary review. Meddr Grønland 134, 8, 35 pp.

Drever, H. I. \& Gribbon, P. W. F. 1968: St Andrews University Greenland projects, 1938-67. Polar Rec. 14, 187-213.

Hald, N. 1973: Preliminary results of the mapping of the Tertiary basalts in western Nûgssuaq. Rapp. Grønlands geol. Unders. 53, 11-19.

Hald, N. \& Pedersen, A. K. 1975: Lithostratigraphy of the Early Tertiary volcanic rocks of central West Greenland. Rapp. Grønlands geol. Unders. 69, 17-24.

Münther, V. 1973: Results from a geological reconnaissance around Svartenhuk Halvø, West Greenland. Rapp. Gronlands geol. Unders. 50, 26 pp.

Pedersen, A. K. 1969: Preliminary notes on the Tertiary lavas of northern Disko. Rapp. Grønlands geol. Unders. 19, 21-24.

Pedersen, A. K. 1970: En petrologisk undersøgelse af tertiære vulkanske bjergarter fra det nordlige Disko. Unpublished thesis, Copenhagen University.

Pedersen, A. K. 1973: Report on field work along the north coast of Disko, 1971. Rapp. Grønlands geol. Unders. 53, 21-27.

Pulvertaft, T. C. R. \& Clarke, D. B. 1966: New mapping on Svartenhuk peninsula. Rapp. Grønlands geol. Unders. 11, 15-17. 